\title{
Spatio-temporal dynamics of sediment transfer systems in landslide-prone Alpine catchments
}

\author{
François Clapuyt $^{1}$, Veerle Vanacker ${ }^{1}$, Marcus Christl $^{2}$, Kristof Van Oost $^{1,4}$, and Fritz Schlunegger ${ }^{3}$ \\ ${ }^{1}$ Earth and Life Institute, Georges Lemaître Centre for Earth and Climate Research, Université catholique de Louvain, \\ Place Pasteur, 3 Bte L4.03.08, 1348 Louvain-la-Neuve, Belgium \\ ${ }^{2}$ Laboratory of Ion Beam Physics, ETH Zurich, Otto-Stern-Weg 5, 8093 Zurich, Switzerland \\ ${ }^{3}$ Institut für Geologie, Universität Bern, Baltzerstrasse 1+3, 3012 Bern, Switzerland \\ ${ }^{4}$ Fonds de la Recherche Scientifique - FNRS, Rue d'Egmont, 5, 1000 Brussels, Belgium
}

Correspondence: François Clapuyt (francois.clapuyt@uclouvain.be)

Received: 18 December 2018 - Discussion started: 11 January 2019

Revised: 20 July 2019 - Accepted: 7 August 2019 - Published: 3 September 2019

\begin{abstract}
Tectonic and geomorphic processes drive landscape evolution over different spatial and temporal scales. In mountainous environments, river incision sets the pace of landscape evolution, and hillslopes respond to channel incision by, e.g., gully retreat, bank erosion, and landslides. Sediment produced during stochastic landslide events leads to mobilization of soil and regolith on the slopes that can later be transported by gravity and water to the river network during phases of hillslope-channel geomorphic coupling. The mechanisms and scales of sediment connectivity mitigate the propagation of sediment pulses throughout the landscape and eventually drive the contribution of landslides to the overall sediment budget of mountainous catchments. However, to constrain the timing of the sediment cascade, the inherent stochastic nature of sediment and transport through landsliding requires an integrated approach accounting for different space scales and timescales. In this paper, we examine the sediment production on hillslopes and evacuation to the river network of one landslide, i.e. the Schimbrig earthflow, affecting the Entle River catchment located in the foothills of the Central Swiss Alps. We quantified sediment fluxes over annual, decadal, and millennial timescales using respectively unmanned aerial vehicle (UAV)-structurefrom-motion (SfM) techniques, classic photogrammetry, and in situ produced cosmogenic radionuclides. At the decadal scale, sediment fluxes quantified for the period 1962-1998 are highly variable and are not directly linked to the intensity of sediment redistribution on the hillslope. At the millennial scale, landslide occurrence perturbs the regional positive
\end{abstract}

linear relationship between sediment fluxes and downstream distance as the landslide-affected Schimbrig catchment is characterized by a decrease in sediment fluxes and a strong variability. Importantly, the average decadal sediment flux of the Schimbrig catchment is 2 orders of magnitude higher than millennial sediment fluxes computed over the same spatial extent. The discrepancy between decadal and millennial sediment fluxes, combined to the highly variable annual sediment evacuation from the hillslopes to the channel network suggest that phases of hillslope-channel geomorphic coupling are short and intermittent. During most of the time, the first-order catchments are transport-limited and sediment dynamics in the headwaters are uncoupled from the fluvial systems. In addition, our unique spatio-temporal database of sediment fluxes highlights the transient character of the intense geomorphic activity of the Schimbrig catchment in a regional context. Its decadal sediment flux is of the same order of magnitude as the background sediment flux going out of the entire Entle River catchment. Over the last 50 years, the Schimbrig catchment, which represents ca. $1 \%$ of the entire study area, provides $65 \%$ of the sediments that the entire Entle catchment will supply over the millennial scale. These results suggest that episodic supply of sediment from landslides during intermittent phases of hillslope-channel geomorphic coupling are averaged out when considering sediment fluxes at longer timescales and larger spatial scales. 


\section{Introduction}

The segmentation of the sediment pathway into distinct cascades is a widely used concept to describe the routing of sediment particles from sources to sinks throughout a landscape (Walling, 1983). Among other factors, e.g. topography, lithology, climate, or tectonic activity (e.g. Aalto et al., 2006; Montgomery and Brandon, 2002; Whipple and Tucker, 1999), the geomorphic coupling and sediment connectivity control the efficiency of sediment transfer in geomorphic systems and condition the pace at which landscapes evolve through time (Bracken et al., 2015; Fryirs, 2013; Harvey, 2001; Heckmann and Schwanghart, 2013). The geomorphic coupling between distinct landscape elements is commonly seen as a measure of how individual landforms are linked through sediment transport (e.g. Harvey, 2001; Heckmann and Schwanghart, 2013), while the term sediment connectivity has been employed for characterizing the transfer of sediments at a larger scale, which includes potential sources and sinks within a geomorphic system (Bracken et al., 2015). Accordingly, a large connectivity requires an implicit geomorphic coupling between distinct landscape units (Bracken et al., 2015).

In this context, most research has focused on how the connectivity between landslides and trunk channels influences the overall sediment budget of a landscape. Because landslides are a dominant source of sediments in mountainous environments (Korup et al., 2010; Vanacker et al., 2003), one can expect that the magnitude and frequency of landsliding (e.g. Crozier and Glade, 1999; Hovius et al., 1997; Malamud et al., 2004) will directly impact the bulk sediment flux of a drainage basin. Nevertheless, the contribution of landslides to the overall sediment budget is still poorly constrained: landslides stochastically supply sediment to the river network, and their geomorphic efficiency varies according to the mechanisms and scales of sediment connectivity (Benda and Dunne, 1997; Bennett et al., 2014). Field studies have shown that the landscape capacity to buffer sediment fluxes from landslides can vary from several years (Berger et al., 2011; Fuller and Marden, 2010) to decades (e.g. Bennett et al., 2013; Schwab et al., 2008) and millennia (e.g. Wang et al., 2017). The inherent stochastic nature of sediment production and transport through landsliding prohibits linear upscaling of small-to-medium-scale geomorphic process assessments, as well as extraction of a particular erosion mechanism from the entire sediment cascade using long-term or large-scale methods (Bennett et al., 2014; Bracken et al., 2015).

Although the analysis of spatio-temporal patterns of the sediment cascade can provide insights into sediment transfer mechanisms in landslide-affected catchments, few studies have attempted to integrate different spatial and temporal scales to assess landscape response to landslide sediment supply and transport. Mackey et al. (2009) compared surface displacement velocities of an earthflow derived from historical aerial photos with sediment transport rates derived from meteoric ${ }^{10} \mathrm{Be}$ inventories. Their study showed that the displacement rate of the Eel earthflow (northern California) was highly episodic in time, as the earthflow acted as a source of sediments over the last 150 years with an erosion rate that was more than 20 times faster than the millennial sediment transport rate. In a similar study, Delong et al. (2012) measured surface displacement rates of the Mill Gulch earthflow from light detection and ranging (lidar) data and compared this data with ${ }^{10} \mathrm{Be}$-derived denudation rates of two adjacent catchments. These authors reported short-term denudation rates (2003 and 2007) that were similar to long-term ones. These two case studies show the assets of a spatio-temporal approach for unravelling the mechanisms of sediment connectivity in landslide-prone environments.

In this study, we examined the propagation of sediment pulses in landslide-prone environments from sediment production at the hillslopes to sediment transport and delivery to the river network. By integrating geomorphic assessments at different spatio-temporal scales and utilizing information on the propagation of sediment pulses along the sediment cascade, we considered the evacuation of landslidederived sediment to the colluvial and fluvial domains. Sediment fluxes were assessed over annual, decadal, and millennial timescales using respectively structure-from-motion (SfM) digital photogrammetry using unmanned aerial vehicle (UAV)-based images, classic photogrammetry, and in situ produced cosmogenic radionuclides. In this study, we posit that sediment fluxes in landslide-prone Alpine catchments can be highly variable in space and time, with long periods of quiescence during which sediment is temporarily stored on the hillslopes and short episodes of high sediment flux when hillslopes and channel are coupled through superimposed debris flows.

\section{Conceptual framework}

Within the sediment cascade, landslides stochastically act as a major sediment source on hillslopes. Here, we propose a conceptual framework (Fig. 1) that may facilitate the quantification of spatio-temporal patterns of sediment cascades in landslide-prone catchments. Landslides can mobilize soil and regolith material (Fig. 1a) that can temporarily accumulate on the slopes (Fig. 1b) and become available for further mobilization and transport downslope. In decoupled hillslope-channel systems, sediments remain on hillslopes as landslide colluvial fans before being gradually depleted and transported to the river network by rainfallinduced superimposed debris flows (e.g. Benda and Dunne, 1997; Schwab et al., 2008). Therefore, the stochastic behaviour of sediment supply on the slopes and sediment transport in the river network gives the landscape a certain capacity to buffer sediment transfer within the sediment cascade (Gran and Czuba, 2017). The temporal scale of the buffering capacity can be highly variable and vary from a num- 


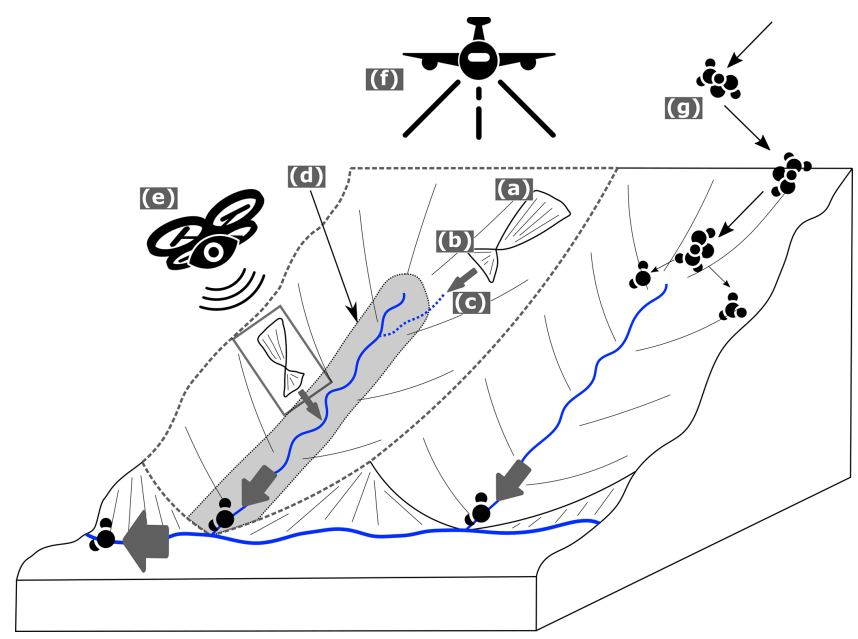

Figure 1. Conceptual framework of the sediment dynamics in Alpine landslide-affected first-order catchments. (a) Landslides are a stochastic process that mobilizes soil and regolith downslope. (b) Landslide-derived material can temporarily be stored on the slopes in landslide colluvial fans, (c) and/or be evacuated by debris flows to the fluvial system. (d) Hillslope-channel geomorphic coupling (by, e.g., slope failures induced by river undercutting) is particularly important for understanding the response of the geomorphic system to sediment pulses. The quantification of sediment fluxes is achieved using (e) UAV-SfM framework, (f) classic photogrammetry, and (g) in situ produced cosmogenic radionuclides.

ber of years (e.g. Berger et al., 2011; Fuller and Marden, 2010; Sutherland et al., 2002) to decades (e.g. Bennett et al., 2013; Schwab et al., 2008) and millennia (e.g. Dingle et al., 2018; Wang et al., 2017; West et al., 2014). In configurations where hillslopes are physically linked to channels (Fig. 1c), the material derived from landsliding is effectively evacuated by the fluvial system (e.g. Berger et al., 2011; Sutherland et al., 2002; Wang et al., 2017). The hillslope-channel geomorphic coupling controls the propagation of sediment pulses from landslides to the river network (Fig. 1d). In catchments with strong hillslope-channel geomorphic coupling by, e.g., debris flows entering the channel reach, we might expect to see a rapid response of the fluvial system to geomorphic events, such as stochastic landslide events. In well-coupled systems, the landslide-derived sediment fluxes for the hillslopes should show good correspondence with the catchment-wide sediment flux.

The downslope propagation of sediment from the hillslopes sources, namely landslides, debris flows, and colluvial fans, to the channel network can be constrained using a time-space approach. In this conceptual framework, we propose to combine information derived from UAV-SfM techniques, classic photogrammetry, and in situ produced cosmogenic radionuclides to quantify spatio-temporal patterns in denudation rates and sediment fluxes. Catchmentscale denudation rates quantify the surface lowering per unit of time $\left(l t^{-1}\right)$ and are scale-invariant. Sediment fluxes record the volume of sediment exported or evacuated from a given surface area per unit of time $\left(l^{3} t^{-1}\right)$, and quantify the rate of sediment transfer between landscape units, i.e. between hillslopes and channels. At annual scale, the geomorphic processes in the hillslope domain $\left(10^{0}-10^{1} \mathrm{~km}^{2}\right)$ can be monitored using very high-resolution topographic reconstructions (Fig. 1e). At the decadal scale, the sediment dynamics of first-order catchments can be quantified from time series of digital elevation models (DEMs) using classic photogrammetry (Fig. 1f). Catchment-averaged cosmogenic radionuclide $(\mathrm{CRN})$-derived denudation rates provide integrated geomorphic process rates over the millennial timescale (Fig. 1g). In the discussion of the results of this study, we will refer to this conceptual framework (Fig. 1) to contextualize the results.

\section{Material and methods}

\subsection{The Entle and Schimbrig catchments}

Our study area is located in the northern foothills of the Central Swiss Alps, between Bern and Lucerne (Fig. 2). The Entle catchment has a drainage basin of $64 \mathrm{~km}^{2}$, with an elevation ranging between $680 \mathrm{~m}$ a.s.l. at the outlet near Entlebuch village and $1815 \mathrm{~m}$ on the Schimbrig summit. The study area lies at the intersection between the Swiss Plateau, i.e. the Molassic basin, and the frontal thrusts of the Alpine orogeny. The molasse unit, covering the lower reaches of the catchment, is composed of Late Oligocene conglomerate bedrock knobs, forming erosion-resistant low ridges. The intermediate part of the catchment is covered by subalpine flysch, while the higher SW-NE-oriented ridge is composed of Cretaceous carbonate rocks of the Helvetic thrust sheet (Schlunegger et al., 2016b; Fig. 2). The Entle catchment is dissected by a $7 \mathrm{~km}$ long central inner gorge with two tributaries, i.e. the Grosse and the Kleine Entle, that are deeply incised into a more than $100 \mathrm{~m}$ thick unconsolidated glacial till. The glacial till was deposited during repetitive and extensive glaciations during the Pleistocene. Lateral and terminal moraines deposited by the Entle glacier during the Last Glacial Maximum (LGM) are dissected by the Grosse and Kleine Entle rivers up to the headwaters (Fig. 2). The inner gorge contains knick zones in its longitudinal profile, and several cut terraces are visible. A ${ }^{10} \mathrm{Be}$-based sediment budget, which covers the last ca. 2000 years, highlighted that incision rates in the inner gorge are more than 4 times higher than in the non-incised reaches (Van den Berg et al., 2012). The study area experiences three types of mass movement processes over distinctive landscape units. Landslides categorized as earthflows mainly affect the flysch areas. This type of mass movement is very common in flysch sedimentary sequences and represents more than $30 \%$ of all mass movements in Switzerland according to Lateltin et al. (1997). Near the summits, rock falls are common phenomena, and 
the sidewalls of river valleys are subject to widespread rotational and translational landslides.

Within the Entle River catchment, an earthflow named Schimbrig has been particularly active over the last 150 years, acting as a sediment factory by excavating and mobilizing sediments because of its deep rotational structure (Clapuyt et al., 2017; Lopez-Saez et al., 2017; Savi et al., 2013; Schwab et al., 2008). It is located in the first-order Schimbrig catchment, the latter draining successively into the Rossloch River and the Kleine Entle, before entering the trunk river, i.e. the Grosse Entle. The earthflow occurs on the hillslopes of the Schimbrig ridge and is not directly connected to the Schimbrig stream, except during short episodes when superimposed debris flows occur (Schwab et al., 2008). The Schimbrig earthflow consists of a fine-grained matrix of silt and mud, with centimetric to decimetric large clasts (Clapuyt et al., 2017). The internal structure of the earthflow is complex with nested rotational units (Clapuyt et al., 2017). Field observations revealed that a major earth slide with a surface lowering of up to $12 \mathrm{~m}$ occurred in the summer of 1994 after a succession of heavy precipitation events, followed by debris flows until March 1995 (Schwab et al., 2008). The intensity and spatial pattern of sediment redistribution, as well as the internal structure of the earthflow have rapidly evolved at the annual and decadal scale (Clapuyt et al., 2017; Schwab et al., 2008). The Schimbrig catchment also experiences scree-slope-like erosion processes in the upper part on the Schimbrig ridge. Eroded material is stored at the foot of the slope, above river sources. Within the Schimbrig catchment, the described earthflow affects ca. $25 \%$ of the area and is the only active process in the catchment.

\subsection{Annual sediment fluxes}

The annual sediment fluxes of the active part of the Schimbrig earthflow (Fig. 3) were derived from time series of very high-resolution topographic datasets from Clapuyt et al. (2017). The earthflow has a rotational structure and is the dominant source of sediment on the hillslopes. By quantitatively comparing topographic datasets, we assessed spatial patterns of surface lowering, i.e. a decrease in ground elevation, and bulging, i.e. an increase in ground elevation. The overall sediment budget of the area affected by the earthflow, i.e. the difference between surface lowering and bulging, is indicative of the change in sediment volume through time. The sediment flux is derived at the base of the hillslopes at the transition between the hillslope and fluvial domains and represents the net flux of sediment from the earthflow to the Schimbrig River. The earthflow acts as a pure sediment source on the hillslope.

The 3-D topographic reconstructions were computed using the structure-from-motion algorithm based on aerial photographs acquired by an unmanned aerial vehicle (Clapuyt et al., 2016). Point clouds were subsequently interpolated into digital surface models (DSMs) at a spatial resolution of $0.04 \mathrm{~m}$, defined based on the density of the point clouds. The accuracy of the time series ranges between 0.20 and $0.24 \mathrm{~m}$. The acquisition dates are October 2013, June 2014 and October 2015. As part of this sediment flux assessment, only the dataset of the 2014-2015 time interval was used because it covers the full spatial domain of the Schimbrig earthflow. The sediment budget was quantified from a digital elevation model of differences (DoDs) between DSMs, using the Geomorphic Change Detection software (Wheaton et al., 2010). In this paper, values are eventually reported on an annual basis instead of over the entire period of interest (as in Clapuyt et al., 2017). Detailed information about the methodology and extended results are available in Clapuyt et al. (2017). Errors reported at the annual scale were computed based on a uniform limit of detection applied to each topographic surface. Therefore, the associated error of the annual sediment fluxes should be seen as a maximum value. It is likely that spatializing the error in very high-resolution topographic measurements, i.e. accounting for the spatial variation in photogrammetric and georeferencing precisions of the reconstructions, would lead to an increase in the signalto-noise ratio as shown by James et al. (2017).

\subsection{Decadal sediment fluxes}

The sediment fluxes at a decadal scale were derived from Schwab et al. (2008), who assessed sediment transport by the Schimbrig earthflow and associated slopes, i.e. the Schimbrig catchment (Fig. 4), and linked it with suspended sediment loads from a gauging station in the trunk stream, i.e. the Waldemme River. The authors based their analysis on a time series of DEMs derived from classic photogrammetry of aerial photographs acquired in 1962, 1986, 1993, and 1998. Each image of stereo-pairs was scanned with a ground resolution of $0.4 \mathrm{~m}$ and georeferenced using a differential GPS. Because of the scarcity of well-recognizable features through time, the associated volumetric errors of the photogrammetric workflow ranged between $2 \%$ for the 1986-1993 time interval and $29 \%$ for the 1962-1986 time interval. The sediment budget based on DEMs provides two metrics. The total sediment displaced corresponds to surface lowering while the total sediment exported per year, i.e. the sediment flux entering the Rossloch River, is the balance between surface lowering and bulging. The ratio between both metrics indicates the percentage of sediment mass evacuated compared to the displaced mass. For this study, we converted the average sediment fluxes that were expressed in tonnes per year into cubic metres per year, using a material density of $2.70 \mathrm{~g} \mathrm{~cm}^{-3}$ following a study by Gong (2005) on similar flysch units in Switzerland. A detailed methodology and results are available in the original paper of Schwab et al. (2008). 


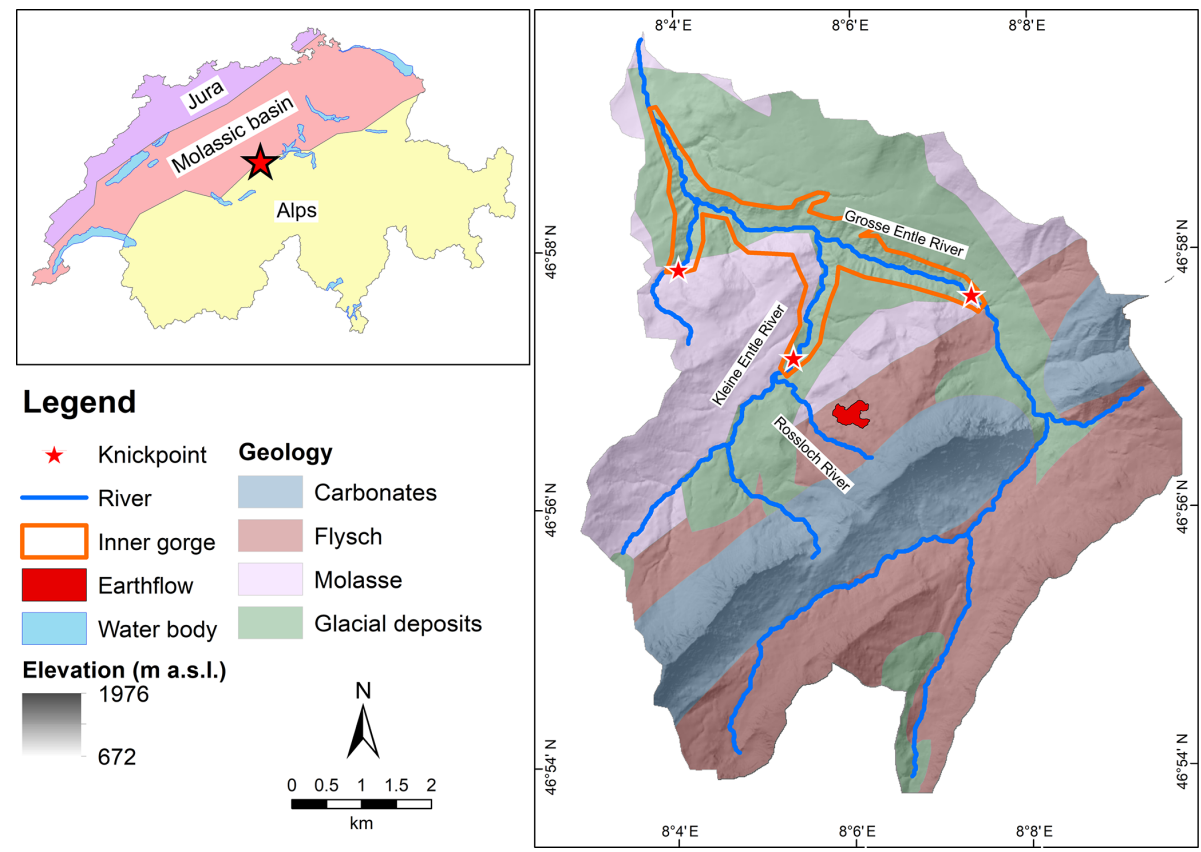

Figure 2. Simplified geological and geomorphological settings of the Entle River catchment (after Van den Berg et al., 2012; Schlunegger et al., 2016a). Inset: location of the study area in Switzerland. Source of the DEM: Swiss Federal Office of Topography Swisstopo (2013).
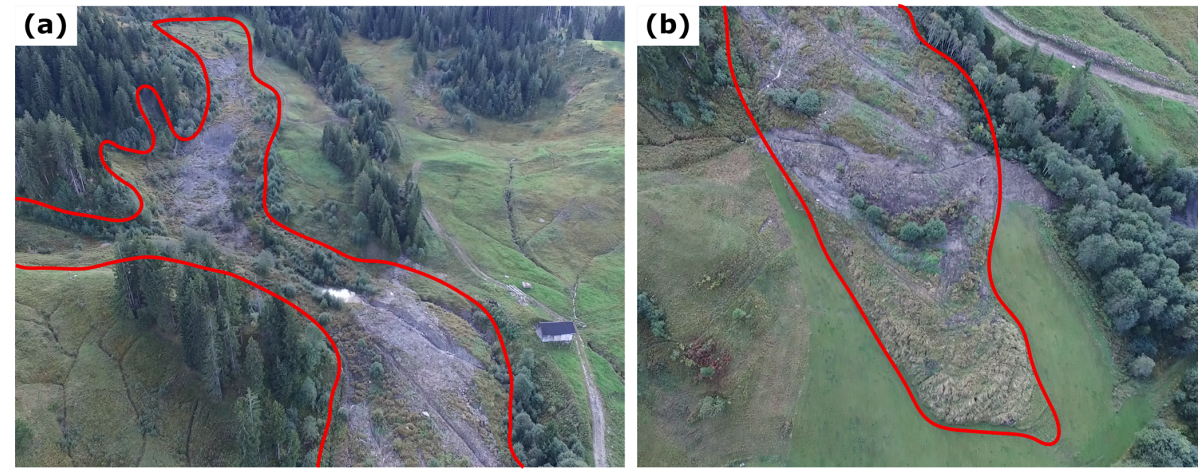

Figure 3. Illustration of the Schimbrig earthflow acting as a source of sediment in the river catchment. (a) Upper part with surface subsidence. (b) Toe of the earthflow with surface bulging. The location of the Schimbrig earthflow is depicted in Fig. 2.

\subsection{Millennial sediment fluxes}

The geomorphic process rates at a millennial scale were assessed from catchment-averaged denudation rates derived from in situ produced cosmogenic radionuclides in fluvial sediments. In order to get a comprehensive dataset on the spatial variation in denudation rates in the Entle catchment, we collected river sand at eight locations in and around the Schimbrig catchment (Fig. 4) and combined the resulting dataset with earlier work by Van den Berg et al. (2012). The new samples were processed following the protocol described in Vanacker et al. (2007), which is similar to the one followed by Van den Berg et al. (2012). After washing and sieving samples to the $0.25-1.00 \mathrm{~mm}$ fraction size, grains were separated using a Frantz isodynamic magnetic separa- tor. The remaining non-magnetic fraction was leached up to 10 times with $10 \%$ hydrochloric acid to remove organic, calcium, and carbonate components. Then, samples were treated up to four times with $5 \%$ hydrofluoric acid in order to dissolve anything but quartz and also to remove any meteoric ${ }^{10} \mathrm{Be}$ left. After the leaching step, $157.8 \mu \mathrm{g}$ of ${ }^{9} \mathrm{Be}$ carrier was added to the clean quartz samples containing ca. $25 \mathrm{~g}$ of material. The purified quartz, i.e. ca. $10 \%$ of the original sample weight, was subsequently dissolved in concentrated hydrofluoric acid, from which beryllium was extracted stepwise using anion-cation exchange column chemistry. Remaining precipitates were oxidized and pressed into copper targets. Finally, ${ }^{10} \mathrm{Be} /{ }^{9} \mathrm{Be}$ ratios were quantified using the $500 \mathrm{kV}$ Tandy facility at ETH Zurich (Christl et al., 2013). These val- 
ues were normalized with the in-house standard S2007N and corrected with a blank ${ }^{10} \mathrm{Be} /{ }^{9} \mathrm{Be}$ ratio of $4.06 \pm 0.23 \times 10^{-15}$. Catchment-wide denudation rates were then computed from the in situ produced ${ }^{10} \mathrm{Be}$ concentrations, i.e. from this study and from earlier data published by Van den Berg et al. (2012), using the catchment-averaged denudation rates from the cosmogenic nuclide (CAIRN) method (Mudd et al., 2016). This open-source calculator uses the topography to weight the ${ }^{10} \mathrm{Be}$ production rate and shielding. A $1 \mathrm{~m}$ digital terrain model (DTM) resampled to $30 \mathrm{~m}$ resolution was used to compute topographic shielding. Snow shielding was averaged for each catchment individually. Snow cover is estimated using an elevation-dependent mean annual snow cover database for Switzerland (Auer, 2003). Following Jonas et al. (2009), an empirical relationship is used to derive the snow water equivalent thickness (SWE; $\mathrm{g} \mathrm{cm}^{-2}$ ). We kept the default parameters from Mudd et al. (2016) to run the CAIRN model, including the sea-level high-latitude production rate of 4.30 atoms $\mathrm{g}^{-1} \mathrm{yr}^{-1}$ (based on Braucher et al., 2011). Long-term denudation rates obtained by the CAIRN calculator were converted into sediment fluxes $\left(\mathrm{m}^{3} \mathrm{yr}^{-1}\right)$, by multiplying them with the catchment area.

\section{Results}

\subsection{Schimbrig earthflow sediment dynamics at the annual scale}

When focusing on the active part of the Schimbrig earthflow (Fig. 4), we obtained a net mass flux of $1000 \pm 4000 \mathrm{~m}^{3} \mathrm{yr}^{-1}$ for the 2014-2015 period (Table 1; Clapuyt et al., 2017). Accounting for the associated error, the sediment flux is considered to be zero. The sediment budget for the 2013-2014 time interval supports this finding. In the eroding sites, the average denudation was $0.8 \pm 0.2 \mathrm{~m} \mathrm{yr}^{-1}$ and equivalent to the accumulation that was observed in the bulging areas (Table 1). For the Schimbrig earthflow, Clapuyt et al. (2017) reported a mean horizontal displacement of ca. $6.30 \mathrm{~m} \mathrm{yr}^{-1}$ in the downslope direction. The UAV-SfM-derived data suggest that the earthflow was in a dynamic equilibrium over the 2014-2015 period, with earthflow-derived material being temporarily stored on the slopes during the period of interest.

Notwithstanding the state of dynamic equilibrium, the data suggest large internal movements with a complex pattern of sediment redistribution along the slope (Clapuyt et al., 2017). A succession of areas with terrain lowering and bulging characterized the earthflow along its longitudinal axis. The earthflow was re-adjusting to a new state of equilibrium after a massive failure that occurred in 1994. The sediment redistribution on the slopes was not associated with an increased sediment export downstream. Between 2013 and 2015, the hillslope domain was disconnected from the fluvial domain.
Table 1. Sediment fluxes for the 2014-2015 time interval from the Schimbrig earthflow reported on an annual basis (modified from Clapuyt et al., 2017).

\begin{tabular}{lrr}
\hline & Estimate & Error $( \pm)$ \\
\hline Total area of surface bulging $\left(\mathrm{m}^{2}\right)$ & 10763 & - \\
Total area of surface lowering $\left(\mathrm{m}^{2}\right)$ & 9730 & - \\
\hline Average rate of surface bulging $\left(\mathrm{m} \mathrm{yr}^{-1}\right)$ & 0.8 & 0.2 \\
Average rate of surface lowering $\left(\mathrm{m} \mathrm{yr}^{-1}\right)$ & 0.8 & 0.2 \\
Average net depth of difference $\left(\mathrm{m} \mathrm{yr}^{-1}\right)$ & 0.05 & 0.15 \\
Sediment flux $\left(\mathrm{m}^{3} \mathrm{yr}^{-1}\right)$ & 1000 & 4000 \\
\hline
\end{tabular}

\subsection{Sediment budget of the Schimbrig catchment at a decadal scale}

Sediment fluxes were computed from 1962 to 1998 over the first-order catchment affected by the earthflow, down to the confluence with the Rossloch River (Table 2; Fig. 4; Schwab et al., 2008). The average sediment flux per year, evacuated from the catchment, varies over time, from $14000 \pm$ $4000 \mathrm{~m}^{3} \mathrm{yr}^{-1}$ for the 1962-1986 period to $850 \pm 20 \mathrm{~m}^{3} \mathrm{yr}^{-1}$ for $1986-1993$ to $24000 \pm 4000 \mathrm{~m}^{3} \mathrm{yr}^{-1}$ for the $1993-1998$ time interval. The data from Schwab et al. (2008) indicate that there is no clear link between the sediment fluxes exported from the Schimbrig catchment and the earthflow dynamics on the hillslopes. This is evident from the fact that the proportion of the mass evacuated from the study area to the total displaced mass varies greatly between $6 \%$ and $89 \%$ (Table 2).

During the $1962-1986$ period, about $89 \%$ of the displaced mass was evacuated from the catchment, suggesting that sediment storage during this period was not significant. In contrast, during the following periods (1986-1993, 1993-1998) when the major earthflow event occurred in 1994, only up to $34 \%$ of the mobilized earthflow material was evacuated.

\subsection{CRN concentrations in the Entle catchment}

The ${ }^{10} \mathrm{Be}$ concentrations reported in this study are spatially and quantitatively consistent with earlier measurements by Norton et al. (2008) and Van den Berg et al. (2012) (Fig. 4). Overall, the ${ }^{10} \mathrm{Be}$ concentrations (Table 3; Fig. 4; Van den Berg et al., 2012) range from $0.15 \pm 0.53 \times 10^{3}$ atoms $\mathrm{g}^{-1}$ in the upper part of the Schimbrig earthflow ( $\mathrm{CH}-\mathrm{ENT}-3)$ to $5.28 \pm 0.26 \times 10^{3}$ atoms $\mathrm{g}^{-1}$ in the upper part of the Entle catchment, i.e. the Rothbach River $(E-9)$. As the ${ }^{10} \mathrm{Be}$ concentrations of the earthflow-affected area are low, relatively high errors are reported for the ${ }^{10} \mathrm{Be}$ concentrations of the earthflow-derived sediment (Table 3). The errors subsequently propagated to the denudation rates, particularly for the samples from the Schimbrig stream draining the earthflow, i.e. $C H$-ENT-1, $C H$-ENT-5, and CH-ENT-8.

When analysing the ${ }^{10} \mathrm{Be}$ concentrations as a function of distance along the stream, we observe a clear and steady de- 
Table 2. Sediment fluxes between 1962 and 1998 (after Schwab et al., 2008).

\begin{tabular}{lrrrrr}
\hline $\begin{array}{l}\text { Time } \\
\text { interval }\end{array}$ & $\begin{array}{r}\text { Total sediment } \\
\text { displaced } \\
\left(10^{3} \mathrm{t}\right)\end{array}$ & $\begin{array}{r}\text { Total sediment } \\
\text { exported } \\
\left(10^{3} \mathrm{t}\right)\end{array}$ & $\begin{array}{r}\text { Average sediment } \\
\text { flux evacuated } \\
\left(\mathrm{m}^{3} \mathrm{yr}^{-1}\right)\end{array}$ & $\begin{array}{r}\text { Error in } \\
\text { sediment } \\
\text { flux }\left(\mathrm{m}^{3} \mathrm{yr}^{-1}\right)\end{array}$ & $\begin{array}{r}\text { Percentage of mass } \\
\text { evacuated compared to } \\
\text { the displaced mass }(\%)\end{array}$ \\
\hline $1962-1986$ & 1003 & 892 & 14000 & 4000 & 89 \\
$1986-1993$ & 272 & 16 & 850 & 20 & 6 \\
$1993-1998$ & 946 & 322 & 24000 & 4000 & 34 \\
$1962-1998$ & 1581 & 1229 & 13000 & 2000 & 78 \\
\hline
\end{tabular}

(a)

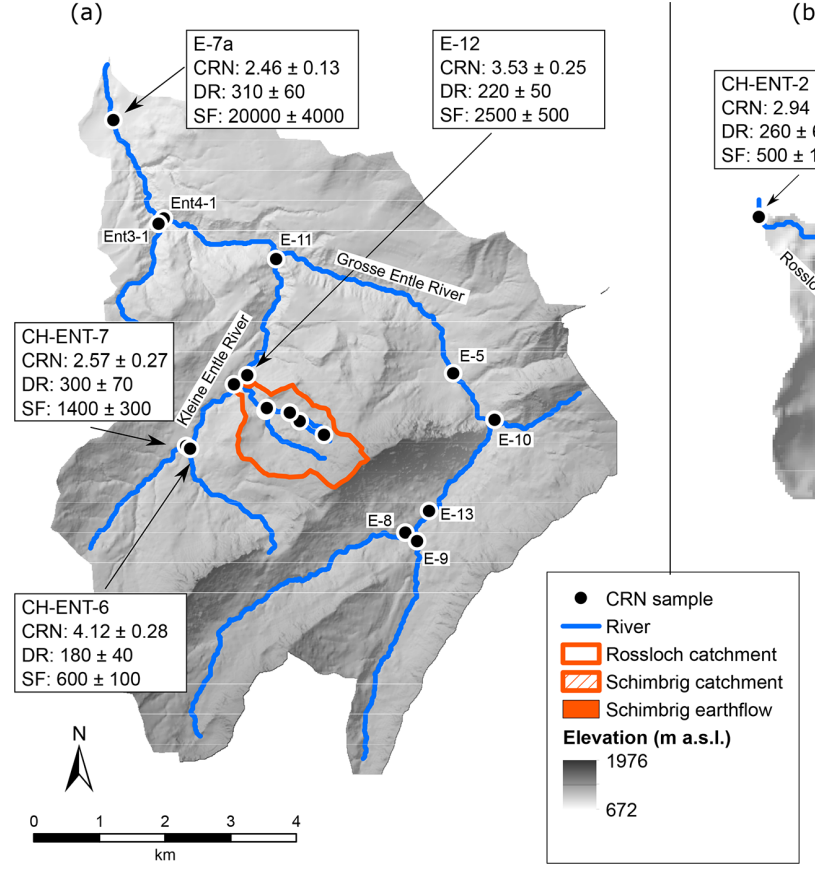

(b)

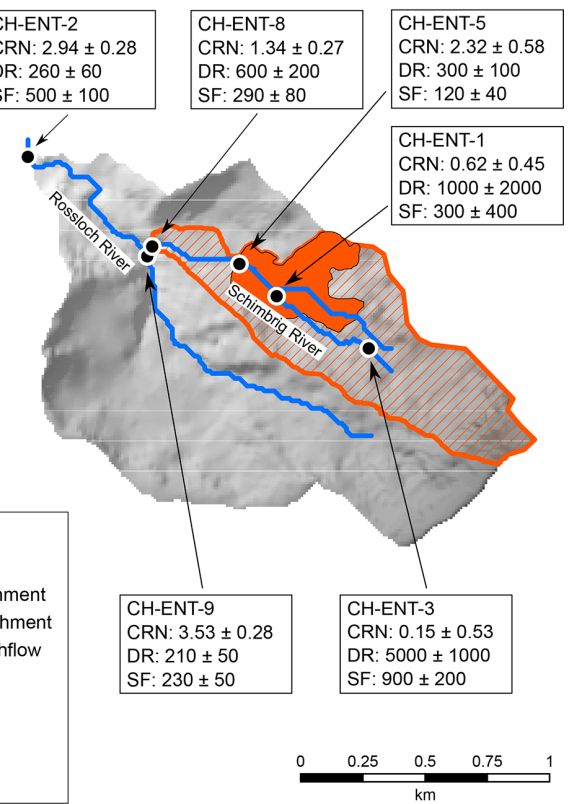

Figure 4. Location of CRN samples in the Entle catchment. CRN concentrations (CRN; $\times 10^{3}$ atoms g $^{-1}$ ), denudation rates (DR; mm kyr ${ }^{-1}$ ) and sediment fluxes (SF; $\mathrm{m}^{3} \mathrm{yr}^{-1}$ ) displayed are discussed in the text. Values are available in Table 3. (a) Entle River and (b) Rossloch River catchments. The Schimbrig catchment is depicted by the hatched polygon within the Rossloch catchment in panel (b). Source of the DEM: Swiss Federal Office of Topography Swisstopo (2013).

crease in ${ }^{10} \mathrm{Be}$ concentrations with increasing downstream distance (and catchment area) for the catchments not affected by active mass movements (Figs. 4, 5). This decrease in CRN concentrations could, at least in part, result from an increase in erosion rates downstream, as suggested in earlier work by Korup and Schlunegger (2007) and Van den Berg et al. (2012), or from a recycling of buried glacial sediment as the river cuts through $100 \mathrm{~m}$ thick unconsolidated glacial deposits in the central part of the catchment (Fig. 2).

Figure 5 illustrates the strong contrast in the downstream change in ${ }^{10} \mathrm{Be}$ concentrations between the earthflowaffected Schimbrig and nearby catchments. Downslope of the Schimbrig earthflow, the river samples $\mathrm{CH}-\mathrm{ENT}-\mathrm{I}, \mathrm{CH}$ ENT-5, and CH-ENT-8 have systematically low CRN concentrations that increase downstream. The latter is likely to reflect poor sediment mixing and long sediment residence time in the alluvial domain. At the confluence with the Ross- loch River, the CRN concentration of the earthflow-affected catchment equals $1.34 \pm 0.27$ atoms $\mathrm{g}^{-1}$ (CH-ENT-8), which is at least 2 times lower than in the neighbouring catchment, i.e. $3.53 \pm 0.28$ atoms $\mathrm{g}^{-1}$ (CH-ENT-9).

\section{Discussion}

\subsection{Sediment fluxes at the millennial scale}

Any variation in sediment mixing capacity or delivery from shielded or reworked sediment to the river channel may dilute or increase the concentration in ${ }^{10} \mathrm{Be}$ in river sediments and lead to over- or underestimation of the catchment-averaged denudation rates and sediment fluxes. Therefore, the geomorphological context of the Entle catchment potentially has three caveats when using ${ }^{10} \mathrm{Be}$ concentrations measured in 


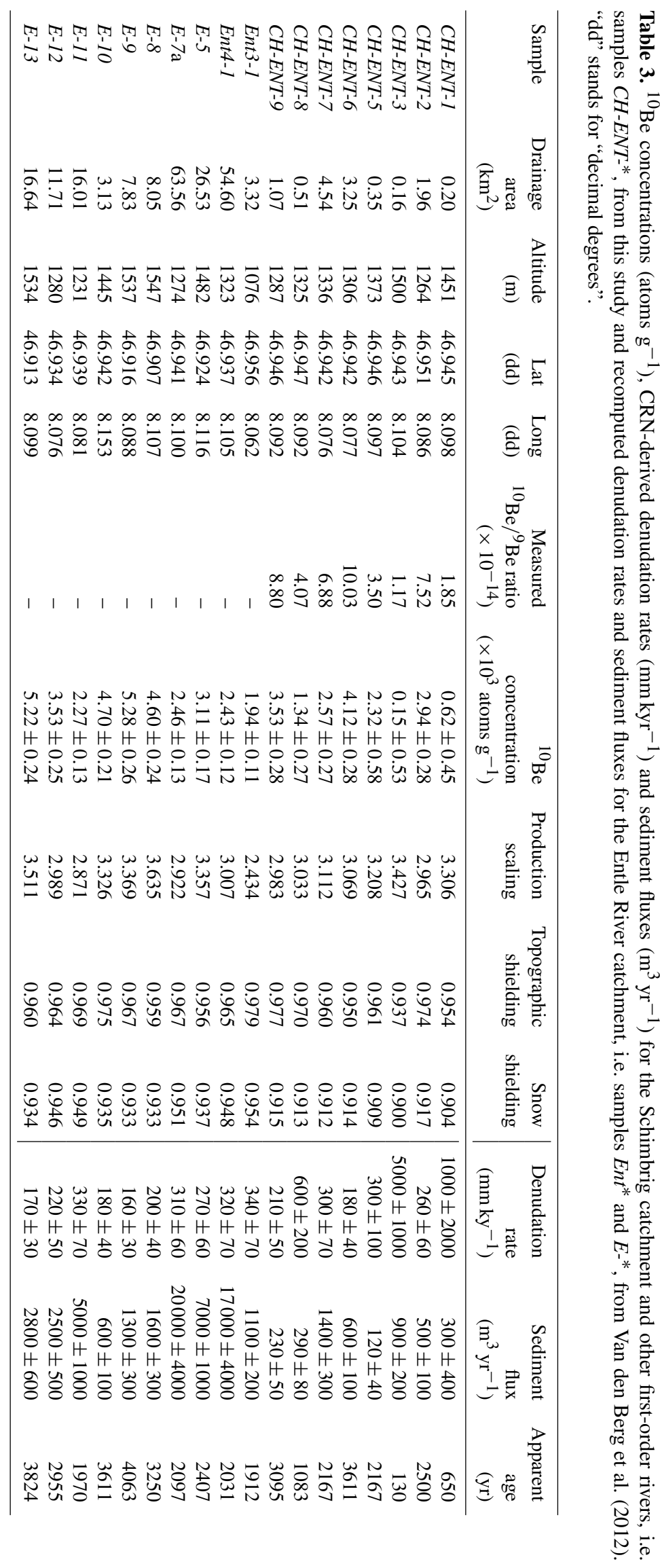




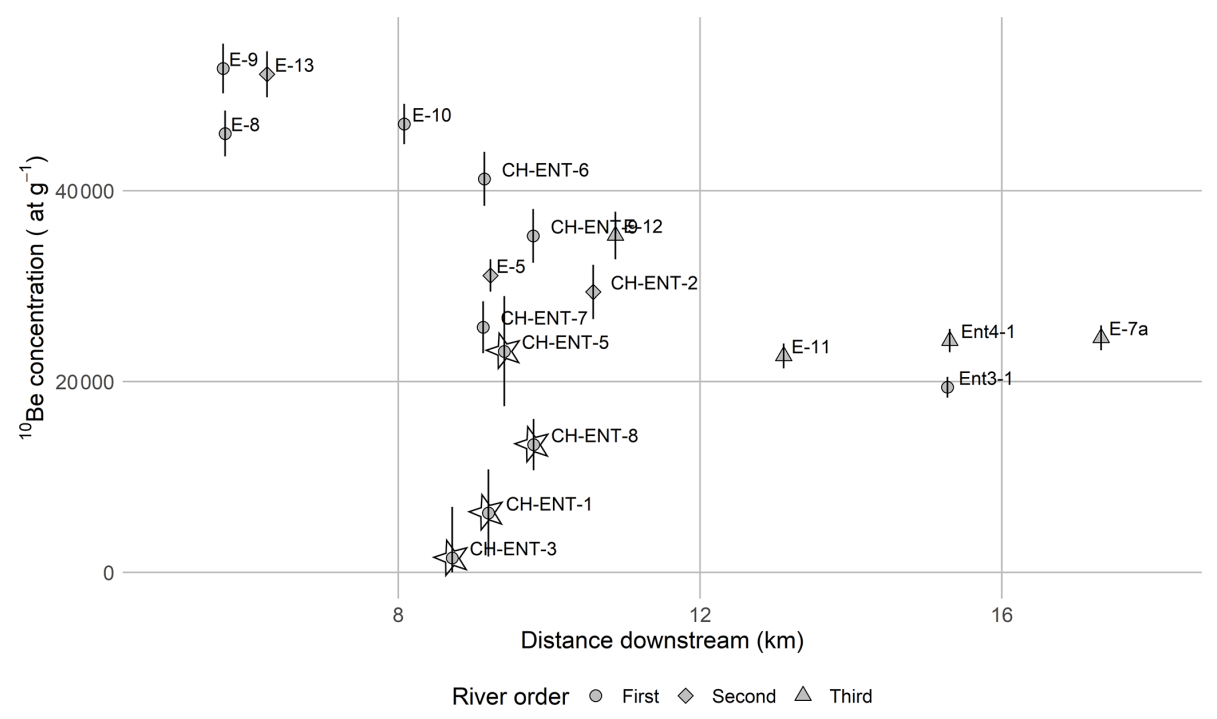

Figure 5. ${ }^{10} \mathrm{Be}$ concentrations (atoms $\mathrm{g}^{-1}$ ) along the river network of the Entle catchment. Downstream distance is computed from the river source to the outlet of the Entle catchment. Samples from the earthflow-affected Schimbrig catchment are marked with a star.

fluvial sediments to draw conclusions about the propagation of sediment pulses throughout the landscape. First, the admixture of buried glacial sediments due to the incision of the Entle River in a $100 \mathrm{~m}$ thick layer of these deposits might lead to dilution of the ${ }^{10} \mathrm{Be}$ signal in the lower reaches. However, in glacial deposits of nearby sites (Trub River catchment, about $15 \mathrm{~km}$ to the west of our study site), Norton et al. (2008) reported ${ }^{10} \mathrm{Be}$ concentrations of glacial deposits reaching $0.76 \pm 0.13 \times 10^{4}$ atoms $\mathrm{g}^{-1}$ at $8.5 \mathrm{~m}$ depth, and $3.58 \pm 0.33 \times 10^{4}$ atoms $\mathrm{g}^{-1}$ at $1.5 \mathrm{~m}$ depth. As these values are about $15 \%$ to $50 \%$ higher than the catchment-wide CRN concentrations of nearby rivers, the incorporation of buried glacial material in the inner gorge is not the principal cause of the low ${ }^{10} \mathrm{Be}$ concentrations that decrease systematically along the Entle River. Second, along with its small size, the presence of an active earthflow in the Schimbrig catchment might violate the assumption of steady-state denudation and sufficient sediment mixing, which are commonly assumed when converting ${ }^{10} \mathrm{Be}$ concentrations of river sediment into catchment-averaged ${ }^{10} \mathrm{Be}$-derived denudation rates (e.g. Savi et al., 2014; Tofelde et al., 2018). We acknowledge that the dilution of ${ }^{10} \mathrm{Be}$ concentrations in river sediment due to stochastic inputs from landslides might lead to an overestimation of $\mathrm{CRN}$-derived denudation rates (Niemi et al., 2005; Yanites et al., 2009). Therefore, CRN-derived denudation rates and subsequent sediment fluxes presented hereunder will be taken as first-order or maximum estimates of the actual values (Puchol et al., 2014). Third, given that sediment production and delivery to the river network is typically stochastic in Alpine environments, the ${ }^{10} \mathrm{Be}$ concentrations in river sediment might be highly variable in space and time as shown by Dingle et al. (2018) and West et al. (2014). Figure 5 illustrates the systematic variation in ${ }^{10} \mathrm{Be}$ concen- trations in the Entle River basin, and the strong coherence between our dataset and previously published data by Norton et al. (2008) and Van den Berg et al. (2012). As such, the effect of the stochastic input of earthflow-derived sediment is likely to be buffered at the scale of the Schimbrig and Rossloch catchments.

Ignoring samples from the earthflow-affected catchment, the long-term denudation rates correlate positively with downstream distance (Table 3; Figs. 4, 6), with values ranging from $160 \pm 30 \mathrm{~mm} \mathrm{kyr}^{-1}(E-9)$ to $340 \pm 70 \mathrm{~mm} \mathrm{kyr}^{-1}$ (Ent3-1). Characterized by a low variability, these values are akin to ${ }^{10} \mathrm{Be}$-derived denudation rates measured in similar Alpine tectonic settings (e.g. Norton et al., 2008). The increase in denudation rates with downstream distance along the Entle River is triggered by the ongoing relief rejuvenation and incision of the inner gorge after the LGM (Van den Berg et al., 2012). The data also indicate that the river network effectively evacuates sediments supplied to the river channel. Accounting for the drainage area at each sampling location, the long-term sediment fluxes (Table 3; Figs. 4, 7) show the same positive correlation with downstream distance. The sediment fluxes range from $600 \pm 100 \mathrm{~m}^{3} \mathrm{yr}^{-1}$ in upper first-order catchments (CH-ENT-6 and E-10) to $20000 \pm 4000 \mathrm{~mm} \mathrm{kyr}^{-1}$ at the outlet of the Grosse Entle River $(E-7 a)$. This increase of 2 orders of magnitude in sediment fluxes downstream corroborates the efficient evacuation of sediment in the inner gorge.

The earthflow-affected catchments show a different pattern that deviates from the overall trend of increasing denudation rates with distance downstream and catchment area. In the first-order Schimbrig catchment, long-term denudation rates correlate negatively with downstream distance (Table 3; Figs. 4, 6). The denudation rates of the earthflow- 

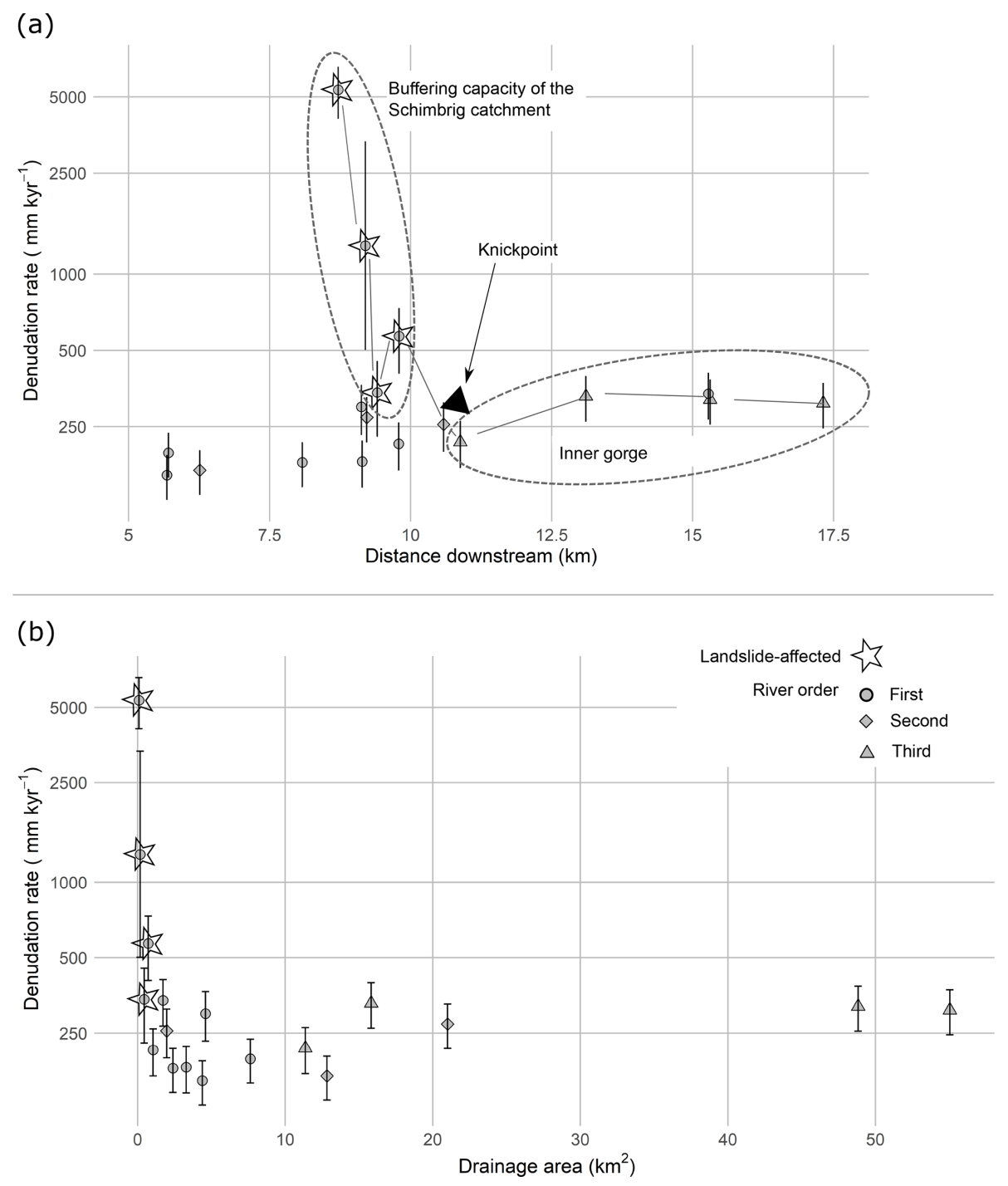

Figure 6. CRN-derived denudation rates $\left(\mathrm{mm} \mathrm{kyr}^{-1}\right)$ in the Entle catchment against (a) downstream distance and (b) drainage area. Downstream distance is computed from the river source to the outlet of the Entle catchment. Samples from the earthflow-affected Schimbrig catchment are marked with a star. The grey lines connect the points that are hydrologically connected and part of the same fluvial system (Schimbrig, Rossloch, Kleine Entle, and Grosse Entle rivers). Denudation rate values on the $y$ axis are shown on a logarithmic scale.

affected first-order catchment are up to 1 order of magnitude higher than the rest of the Entle catchment, with values ranging between $300 \pm 100 \mathrm{~mm} \mathrm{kyr}^{-1}$ in the intermediate part (CH-ENT-5) and 5000 $\pm 1000 \mathrm{~mm} \mathrm{kyr}^{-1}$ (CH-ENT-3) in the upper part of the Schimbrig catchment. The variability in denudation rates along the river is very high, with a 1 order of magnitude difference between minimum and maximum values, and it is spatially highly variable. For example, the denudation rate in $\mathrm{CH}$-ENT-5 is lower than the sites directly up- and downstream of this sampling location, reflecting the stochastic character of the sediment delivery from the earthflow. The decrease in denudation rates with catchment area suggests that material initially displaced by the earthflow is not directly evacuated to the river network but remains on the slopes, hence accumulating ${ }^{10} \mathrm{Be}$ atoms in the colluvial domain. Given that the catchment area of the first-order earthflow-affected catchments is small, the absolute sediment fluxes are low with values ranging between $120 \pm 40$ and $900 \pm 200 \mathrm{~m}^{3} \mathrm{yr}^{-1}$. These long-term sediment fluxes computed for the Rossloch catchment, i.e. including the Schimbrig area, are 1 to 2 orders of magnitude lower than values computed in other parts of the Entle catchment (Figs. 4, 7).

The impact of landsliding on the long-term sediment dynamics can be evaluated by comparing the denudation rates of the two intersecting catchments at the confluence with the Rossloch River. At the outlet of the Schimbrig catchment, the denudation rate, i.e. $600 \pm 200 \mathrm{~mm} \mathrm{kyr}^{-1}$ (CH-ENT-8), is at least 2 times higher than in the neighbouring catchment, 


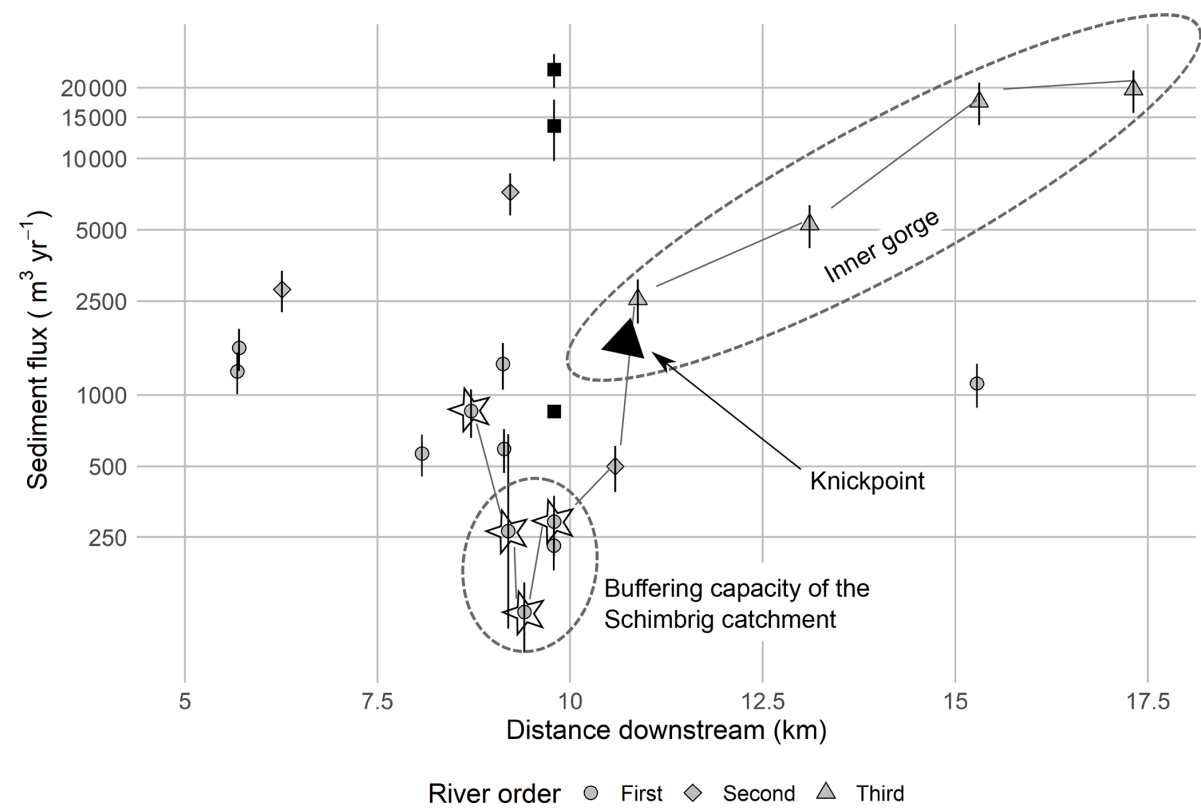

Figure 7. CRN-derived sediment fluxes $\left(\mathrm{m}^{3} \mathrm{yr}^{-1}\right)$ along the river network of the Entle catchment. Downstream distance is computed from the river source to the outlet of the Entle catchment. Samples from the earthflow-affected Schimbrig catchment are marked with a star. Black square markers represent the sediment flux computed by Schwab et al. (2008) for the period 1962-1998. Grey lines present the downstream sequence of denudation rates along the Schimbrig, Rossloch, Kleine Entle, and Grosse Entle rivers. Sediment flux values on the $y$ axis are shown on a logarithmic scale.

i.e. $210 \pm 50 \mathrm{~mm} \mathrm{kyr}^{-1}(\mathrm{CH}-E N T-9)$. The difference in denudation rates between the two headwater catchments illustrates that the sediment dynamics of both catchments were probably very different over the last thousands of years as a function of the stochastic input of sediment from landslides (Fig. 1). When accounting for their catchment area, the sediment fluxes are very similar though with values of respectively $290 \pm 80 \mathrm{~m}^{3} \mathrm{yr}^{-1}(C H-E N T-8)$ and $230 \pm 50 \mathrm{~m}^{3} \mathrm{yr}^{-1}$ (CH-ENT-9).

\subsection{Temporal upscaling: the stochastic nature of landsliding}

Characterized by a relatively gentle Alpine topography, the millennial geomorphic activity of the study area is moderate in intensity. In comparison, the average CRN-derived denudation rate is $270 \pm 140 \mathrm{~mm} \mathrm{kyr}^{-1}$ in similar surrounding areas, i.e. in the Alpine foreland, but increases to $900 \pm$ $300 \mathrm{~mm} \mathrm{kyr}^{-1}$ in the high crystalline Alps (Wittmann et al., 2007). Dendrogeomorphological data confirmed that the Entle River catchment has been affected by an active earthflow at least over the past 150 years (Lopez-Saez et al., 2017; Savi et al., 2013). Given the extent of its active part, i.e. ca. $0.5 \mathrm{~km}^{2}$, the Schimbrig earthflow is a larger-thanaverage landslide (Stark and Hovius, 2001). Therefore, according to the magnitude-frequency distribution of landslides (e.g. Hovius et al., 1997), this type of phenomenon is generally relatively infrequent, i.e. between $10^{-2}$ and
$10^{-3}$ events $\mathrm{km}^{-2} \mathrm{yr}^{-1}$. The mean annual horizontal displacements (Fig. 1a) that we measured within the earthflow, i.e. ca. $6.30 \mathrm{~m} \mathrm{yr}^{-1}$ for the period 2014-2015, are relatively high in comparison with decimetric displacements reported in the western Slovakian Carpathians (Prokešová et al., 2014), submetric $\left(<2 \mathrm{~m} \mathrm{yr}^{-1}\right)$ displacements reported for the Eel earthflow in California (Mackey et al., 2009), and metric to decametric displacements for the Super-Sauze landslide in southern French Alps (Niethammer et al., 2012). The toe of the earthflow experienced a downslope movement of ca. $55 \mathrm{~m}$ between June 2014 and October 2015 (Fig. 1b, Clapuyt et al., 2017). Despite the important internal reorganization of the Schimbrig earthflow, its net sediment budget is roughly in equilibrium: sediment transfer from the colluvial to the fluvial domain (Fig. 1c) is minimal over the period 2013-2015. The sediment mobilized by the earthflow is buffered in the colluvial domain, due to the decoupling of the hillslope-channel system (Fig. 1d) over the annual timescale. In contrast to the limited annual sediment flux (period 20132015) of the Schimbrig catchment, its decadal sediment flux (period 1962-1998) equals $13000 \pm 2000 \mathrm{~m}^{3} \mathrm{yr}^{-1}$ (Table 2; Fig. 7). The decadal sediment flux is 2 orders of magnitude higher than the sediment fluxes computed at the millennial timescale over the same spatial extent, i.e. $290 \pm 80 \mathrm{~m}^{3} \mathrm{yr}^{-1}$ $(C H-E N T-8)$. We note here that the potential overestimation of ${ }^{10} \mathrm{Be}$-derived denudation rates due to the addition of ${ }^{10} \mathrm{Be}$ poor material from the earthflow (discussed in Sect. 5.1) does not affect our interpretation. 


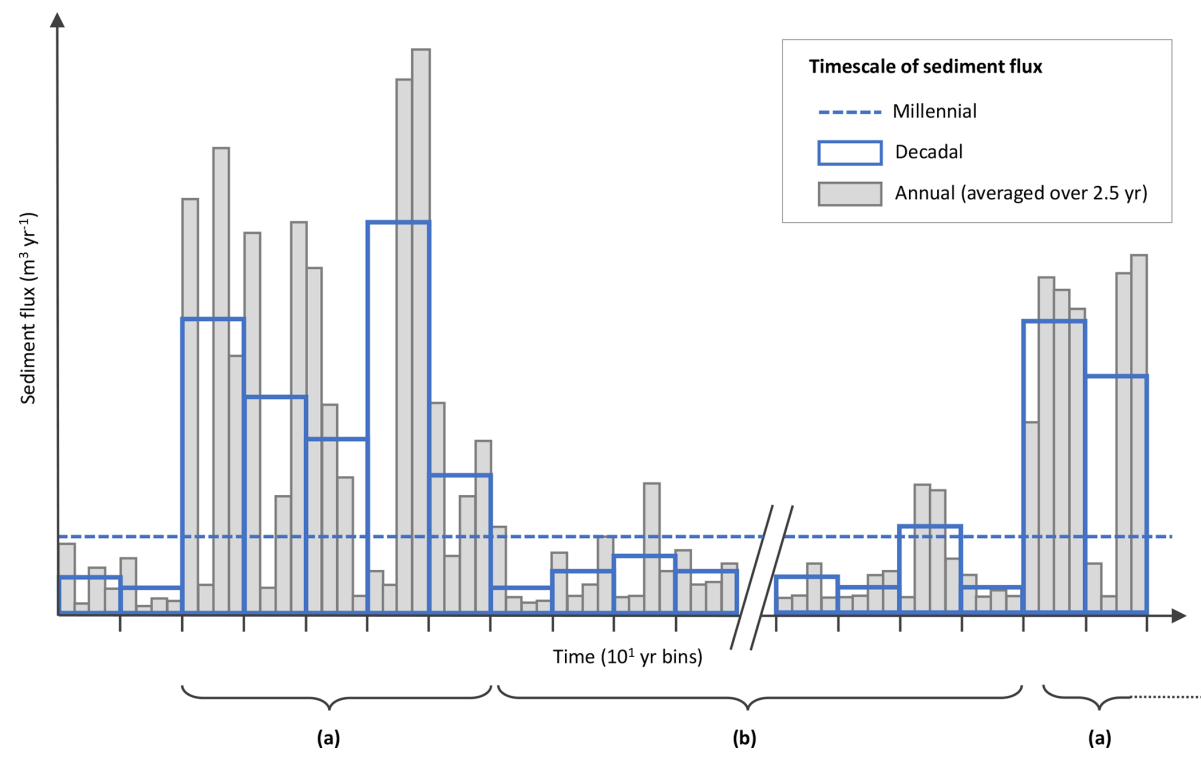

Figure 8. Conceptual representation of the sediment fluxes over different timescales at the outlet of a first-order river catchment. (a) Periods of high hillslope activity due to a landslide sediment pulse, resulting in intermittent hillslope-channel connections and in sediment export to the river network at the annual scale. (b) Periods of low hillslope activity both at the annual and decadal scales, due to poor sediment availability on slopes.

The sediment fluxes measured over different timescales reveal the episodic character of sediment production, delivery, and transport out of first-order Alpine catchments, such as the Schimbrig and Rossloch catchments (Fig. 1). Landslides such as the Schimbrig earthflow generate sediment (Fig. 1a) that is temporarily stored in the colluvial domain (Fig. 1b) and continues to accumulate ${ }^{10} \mathrm{Be}$ nuclides during storage. During short phases when hillslope and channel systems are coupled, the colluvial deposits are evacuated out of the firstorder sediment stores. The discrepancy between decadal and millennial sediment fluxes illustrates that these phases of hillslope-channel geomorphic coupling are short-lived and intermittent and interrupt long periods of largely uncoupled colluvial and fluvial geomorphic systems (Fig. 8). During most of the time, the first-order catchments are transportlimited, and sediment dynamics in the headwaters are uncoupled from the fluvial systems.

\subsection{Spatial upscaling: the importance of landsliding for sediment budgets}

Episodic landslides, such as the Schimbrig earthflow, have the potential to mobilize large quantities of sediment at annual or decadal timescales. The average sediment flux at the decadal scale (1962-1998) out of the Schimbrig catchment, i.e. $13000 \pm 2000 \mathrm{~m}^{3} \mathrm{yr}^{-1}$ (Table 2; Fig. 7), represents about $65 \%$ of the average sediment flux out of the Entle catchment at the millennial scale, i.e. $20000 \pm 4000 \mathrm{~m}^{3} \mathrm{yr}^{-1}(E-7 a$; Table 3; Fig. 7). This illustrates that landslide-affected catchments can act as principal point sources of sediment, as a sub-catchment covering $1 \%$ of the area can provide $65 \%$ of the total sediment flux. The higher-order river network, i.e. the Kleine and Grosse Entle rivers, attenuates decadal sediment pulses through the sediment cascade, during which subsequent erosion and deposition occur over centennial timescales. The propagation of the sediment pulses (from, e.g., landslides) across the channel network is largely controlled by the hillslope-channel geomorphic coupling and the transport capacity of the fluvial systems. The latter act as non-linear filters that smooth out spikes produced by episodic landslide disturbances as also suggested by Jerolmack and Paola (2010). In this sense, we can consider the episodic supply of sediment from landslides during intermittent phases of hillslope-channel coupling as noise that is averaged out when considering sediment fluxes at longer timescales and larger spatial scales. As our data show, one single disturbance (such as an earthflow) does not necessarily have an impact on the long-term sediment budget of first-order catchments. Rather, it is the cumulated effect of multiple landslides, which are intermittently connected to the channel network at the decadal scale, along with sediment transport, that may regulate sediment fluxes at the regional spatial scale over the millennial timescale.

\section{Conclusions}

To better constrain the evacuation of sediment produced by landslides on hillslopes and their propagation in the channel network, we compiled geomorphic assessments at different spatio-temporal scales of the Entle River catchment located in the foothills of the Central Swiss Alps. This 
$64 \mathrm{~km}^{2}$ mountainous river catchment has been affected by the Schimbrig earthflow for more than 150 years. We quantified (or benefitted from previous studies of) sediment fluxes over annual, decadal, and millennial timescales using respectively UAV-SfM-based 3-D topographic reconstructions, classic photogrammetry, and in situ produced ${ }^{10} \mathrm{Be}$ cosmogenic radionuclides. Our unique spatio-temporal database of sediment fluxes highlights the episodic character of sediment production, delivery, and transport out of first-order river catchments, i.e. the Schimbrig and Rossloch catchments. A discrepancy of 2 orders of magnitude is observed between annual, decadal, and millennial sediment fluxes at the outlet of the Schimbrig catchment. It illustrates that phases of hillslope-channel geomorphic coupling are short-lived and intermittent, and it interrupts long periods of largely uncoupled colluvial and fluvial geomorphic systems. During most of the time, the first-order catchments are transportlimited, and sediment dynamics in the headwaters are uncoupled from the fluvial systems.

Landslides such as the Schimbrig earthflow act as point sources of sediment. Although they represent only $1 \%$ of the total surface area, they can produce intermittently about $65 \%$ of the average regional sediment flux. The impact of a single sediment pulse is strongly attenuated at larger spatial and temporal scales by sediment transport mechanisms. The latter tend to smooth out the spikes in sediment flux delivered by episodic landslide events. Therefore, the accumulation of multiple sediment pulses, which are intermittently delivered to the channel network during phases of hillslope-channel geomorphic coupling, has rather a measurable impact on the regional pattern of sediment fluxes.

Data availability. All datasets and code are available upon request. Please contact the first author for details.

Author contributions. FC and VV conceived the conceptual model on spatio-temporal sediment dynamics and designed the research project. FC performed field surveys, prepared the samples for CRN analysis with help of VV and JS, and was responsible for data analyses. MC performed the AMS measurements at ETH Zurich. KVO and FS contributed to the implementation of the research and to the analysis of the results. FC took the lead in writing the paper. All authors contributed to shaping the research, analyses, and paper.

Competing interests. The authors declare that they have no conflict of interest.

Acknowledgements. The authors would like to thank Jérome Schoonejans for the extended help and the careful supervision of the CRN extraction procedure in the Cosmo Laboratory of the Georges Lemaitre Centre for Earth and Climate Research at the Université catholique de Louvain. We extend our thanks to Marco Bravin for the help with sample leaching in the soil lab. We also acknowledge Romain Delunel from Universität Bern for the computation of the snow shielding factors, which serve as inputs to derive long-term denudation rates. Efficient and reproducible research is possible thanks to open-source algorithms, such as CAIRN, i.e. the CRN-derived denudation rates calculator, developed by Simon Mudd and his colleagues. Finally, we would like to thank Luca Malatesta and one anonymous reviewer for their constructive comments, which helped us to better structure the paper and improve its quality.

Review statement. This paper was edited by Arjen Stroeven and reviewed by Luca C. Malatesta and one anonymous referee.

\section{References}

Aalto, R., Dunne, T., and Guyot, J. L.: Geomorphic controls on Andean denudation rates, J. Geol., 114, 85-99, https://doi.org/10.1086/498101, 2006.

Auer, M.: Regionalisierung von Schneeparametern - Eine Methode zur Darstellung von Schneeparametern im Relief, University of Berne, 97 pp., 2003.

Benda, L. and Dunne, T.: Stochastic forcing of sediment supply to channel networks from landsliding and debris flow, Water Resour. Res., 33, 2849-2863, https://doi.org/10.1029/97WR02388, 1997.

Bennett, G. L., Molnar, P., McArdell, B. W., Schlunegger, F., and Burlando, P.: Patterns and controls of sediment production, transfer and yield in the Illgraben, Geomorphology, 188, 68-82, https://doi.org/10.1016/j.geomorph.2012.11.029, 2013.

Bennett, G. L., Molnar, P., McArdell, B. W., and Burlando, P.: A probabilistic sediment cascade model of sediment transfer in the Illgraben, Water Resour. Res., 50, 1225-1244, https://doi.org/10.1002/2013WR013806, 2014.

Berger, C., McArdell, B. W., and Schlunegger, F.: Sediment transfer patterns at the Illgraben catchment, Switzerland: Implications for the time scales of debris flow activities, Geomorphology, 125, 421-432, https://doi.org/10.1016/j.geomorph.2010.10.019, 2011.

Bracken, L. J., Turnbull, L., Wainwright, J., and Bogaart, P.: Sediment connectivity: A framework for understanding sediment transfer at multiple scales, Earth Surf. Process. Land., 40, $177-$ 188, https://doi.org/10.1002/esp.3635, 2015.

Braucher, R., Merchel, S., Borgomano, J., and Bourlès, D. L.: Production of cosmogenic radionuclides at great depth: A multi element approach, Earth Planet. Sc. Lett., 309, 1-9, https://doi.org/10.1016/j.eps1.2011.06.036, 2011.

Christl, M., Vockenhuber, C., Kubik, P. W., Wacker, L., Lachner, J., Alfimov, V., and Synal, H. A.: The ETH Zurich AMS facilities: Performance parameters and reference materials, Nucl. Instruments Methods Phys. Res. Sect. B, 294, 29-38, https://doi.org/10.1016/j.nimb.2012.03.004, 2013.

Clapuyt, F., Vanacker, V., and Van Oost, K.: Reproducibility of UAV-based earth topography reconstructions based on Structure-from-Motion algorithms, Geomorphology, 260, 4-15, https://doi.org/10.1016/j.geomorph.2015.05.011, 2016. 
Clapuyt, F., Vanacker, V., Schlunegger, F., and Van Oost, K.: Unravelling earth flow dynamics with 3-D time series derived from UAV-SfM models, Earth Surf. Dynam., 5, 791-806, https://doi.org/10.5194/esurf-5-791-2017, 2017.

Crozier, M. J. and Glade, T.: Frequency and magnitude of landsliding: fundamental research issues, Z. Geomorphol., 115, 141$155,1999$.

Delong, S. B., Prentice, C. S., Hilley, G. E., and Ebert, Y.: Multitemporal ALSM change detection, sediment delivery, and process mapping at an active earthflow, Earth Surf. Process. Land., 37, 262-272, https://doi.org/10.1002/esp.2234, 2012.

Dingle, E. H., Sinclair, H. D., Attal, M., Rodés, Á., and Singh, V.: Temporal variability in detrital ${ }^{10} \mathrm{Be}$ concentrations in a large Himalayan catchment, Earth Surf. Dynam., 6, 611-635, https://doi.org/10.5194/esurf-6-611-2018, 2018.

Fryirs, K.: (Dis)Connectivity in catchment sediment cascades: A fresh look at the sediment delivery problem, Earth Surf. Process. Land., 38, 30-46, https://doi.org/10.1002/esp.3242, 2013.

Fuller, I. C. and Marden, M.: Rapid channel response to variability in sediment supply: Cutting and filling of the Tarndale Fan, Waipaoa catchment, New Zealand, Mar. Geol., 270, 45-54, https://doi.org/10.1016/j.margeo.2009.10.004, 2010.

Gong, G.: Physical Properties of Alpine Rocks: A Laboratory Investigation, University of Geneva, 142 pp., 2005.

Gran, K. B. and Czuba, J. A.: Sediment pulse evolution and the role of network structure, Geomorphology, 277, 17-30, https://doi.org/10.1016/j.geomorph.2015.12.015, 2017.

Harvey, A. M.: Coupling between hillslopes and channels in upland fluvial systems: implications for landscape sensitivity, illustrated from the Howgill Fells, northwest England, Catena, 42, 225-250, 2001

Heckmann, T. and Schwanghart, W.: Geomorphic coupling and sediment connectivity in an alpine catchment - Exploring sediment cascades using graph theory, Geomorphology, 182, 89-103, https://doi.org/10.1016/j.geomorph.2012.10.033, 2013.

Hovius, N., Stark, C. P., and Allen, P. A.: Sediment flux from a mountain belt derived by landslide mapping, Geology, 25, 231234, 1997.

James, M. R., Robson, S., and Smith, M. W.: 3-D uncertainty-based topographic change detection with structure-from-motion photogrammetry: Precision maps for ground control and directly georeferenced surveys, Earth Surf. Process. Land., 42, 17691788, https://doi.org/10.1002/esp.4125, 2017.

Jerolmack, D. J. and Paola, C.: Shredding of environmental signals by sediment transport, Geophys. Res. Lett., 37, 1-5, https://doi.org/10.1029/2010GL044638, 2010.

Jonas, T., Marty, C., and Magnusson, J.: Estimating the snow water equivalent from snow depth measurements in the Swiss Alps, J. Hydrol., 378, 161-167, https://doi.org/10.1016/j.jhydrol.2009.09.021, 2009.

Korup, O. and Schlunegger, F.: Bedrock landsliding, river incision, and transience of geomorphic hillslope-channel coupling: Evidence from inner gorges in the Swiss Alps, J. Geophys. Res.Earth, 112, F0302, https://doi.org/10.1029/2006JF000710, 2007.

Korup, O., Densmore, A. L., and Schlunegger, F.: The role of landslides in mountain range evolution, Geomorphology, 120, 77-90, https://doi.org/10.1016/j.geomorph.2009.09.017, 2010.

Lateltin, A., Beer, O., Raetzo, C., Lateltin, O., Raetzo, H., and Caron, C.: Landslides in flysch terranes of Switzerland?: causal factors and climate change Landslides in Flysch terranes of Switzerland?: Causal factors and climate change, Eclogae Geol. Helv., 90, 401-406, 1997.

Lopez-Saez, J., Morel, P., Corona, C., Bommer-Denns, B., Schlunegger, F., Berger, F., and Stoffel, M.: Tree-ring reconstruction of reactivation phases of the Schimbrig landslide (Swiss Alps), Géomorpho. Reli. Process. Environ., 23, 265-276, https://doi.org/10.4000/geomorphologie.11825, 2017.

Mackey, B. H., Roering, J. J., and McKean, J. A.: Longterm kinematics and sediment flux of an active earthflow, Eel River, California, Geology, 37, 803-806, https://doi.org/10.1130/G30136A.1, 2009.

Malamud, B. D., Turcotte, D. L., Guzzetti, F., and Reichenbach, P.: Landslide inventories and their statistical properties, Earth Surf. Process. Land., 29, 687-711, https://doi.org/10.1002/esp.1064, 2004.

Montgomery, D. R. and Brandon, M. T.: Topographic controls on erosion rates in tectonically active mountain ranges, Earth Planet. Sc. Lett., 201, 481-489, https://doi.org/10.1016/S0012821X(02)00725-2, 2002.

Mudd, S. M., Harel, M. A., Hurst, M. D., Grieve, S. W. D., and Marrero, S. M.: The CAIRN method: Automated, reproducible calculation of catchment-averaged denudation rates from cosmogenic nuclide concentrations, Earth Surf. Dynam., 4, 655-674, https://doi.org/10.5194/esurf-4-655-2016, 2016.

Niemi, N. A., Oskin, M., Burbank, D. W., Heimsath, A. M., and Gabet, E. J.: Effects of bedrock landslides on cosmogenically determined erosion rates, Earth Planet. Sc. Lett., 237, 480-498, https://doi.org/10.1016/j.eps1.2005.07.009, 2005.

Niethammer, U., James, M. R., Rothmund, S., Travelletti, J., and Joswig, M.: UAV-based remote sensing of the SuperSauze landslide: Evaluation and results, Eng. Geol., 128, 2-11, https://doi.org/10.1016/j.enggeo.2011.03.012, 2012.

Norton, K. P., von Blanckenburg, F., Schlunegger, F., Schwab, M., and Kubik, P. W.: Cosmogenic nuclide-based investigation of spatial erosion and hillslope channel coupling in the transient foreland of the Swiss Alps, Geomorphology, 95, 474-486, https://doi.org/10.1016/j.geomorph.2007.07.013, 2008.

Prokešová, R., Kardoš, M., Tábořík, P., Medved'ová, A., Stacke, V., and Chudý, F.: Kinematic behaviour of a large earthflow defined by surface displacement monitoring, DEM differencing, and ERT imaging, Geomorphology, 224, 86-101, https://doi.org/10.1016/j.geomorph.2014.06.029, 2014.

Puchol, N., Lavé, J., Lupker, M., Blard, P.-H., Gallo, F., FranceLanord, C., and Team, A.: Grain-size dependent concentration of cosmogenic ${ }^{10} \mathrm{Be}$ and erosion dynamics in a landslidedominated Himalayan watershed, Geomorphology, 224, 55-68, https://doi.org/10.1016/j.geomorph.2014.06.019, 2014.

Savi, S., Schneuwly-Bollschweiler, M., Bommer-Denns, B., Stoffel, M., and Schlunegger, F.: Geomorphic coupling between hillslopes and channels in the Swiss Alps, Earth Surf. Process. Land., 38, 959-969, https://doi.org/10.1002/esp.3342, 2013.

Savi, S., Norton, K., Picotti, V., Brardinoni, F., Akçar, N., Kubik, P. W., Delunel, R., and Schlunegger, F.: Effects of sediment mixing on ${ }^{10} \mathrm{Be}$ concentrations in the Zielbach catchment, central-eastern Italian Alps, Quat. Geochronol., 19, 148-162, https://doi.org/10.1016/j.quageo.2013.01.006, 2014.

Schlunegger, F., Anspach, O., Bieri, B., Böning, P., Kaufmann, Y., Lahl, K., Lonschinski, M., Mollet, H., Sachse, D., Schubert, 
C., Stöckli, G., and Zander, I.: Geologische Karte der Schweiz, Kartenblatt 1169 Schüpfheim 1:25000, Bundesamt für Landestopographie swisstopo, 2016a.

Schlunegger, F., Jost, J., Grünig, A., and Trüssel, M.: Erläuterungen, Geologischer Atlas der Schweiz, Kartenblatt 1169 Schüpfheim $1: 25000$, Bundesamt für Landestopographie swisstopo, 107 pp., $2016 b$.

Schwab, M., Rieke-Zapp, D., Schneider, H., Liniger, M., and Schlunegger, F.: Landsliding and sediment flux in the Central Swiss Alps: A photogrammetric study of the Schimbrig landslide, Entlebuch, Geomorphology, 97, 392-406, https://doi.org/10.1016/j.geomorph.2007.08.019, 2008.

Stark, C. P. and Hovius, N.: The characterization of landslide size distribution, Geophys. Res. Lett., 28, 1091-1094, 2001.

Sutherland, D. G., Ball, M. H., Hilton, S. J., and Lisle, T. E.: Evolution of a landslide-induced sediment wave in the Navarro River, California, Bull. Geol. Soc. Am., 114, 1036-1048, 2002.

Swiss Federal Office of Topography Swisstopo: swissALTI3D, the high precision digital elevation model of Switzerland, Swisstopo, Wabern, available at: https://shop.swisstopo.admin.ch/en/ products/height_models/alti3D, last access: 20 September 2013.

Tofelde, S., Duesing, W., Schildgen, T. F., Wickert, A. D., Wittmann, H., Alonso, R. N., and Strecker, M.: Effects of deepseated versus shallow hillslope processes on cosmogenic ${ }^{10} \mathrm{Be}$ concentrations in fluvial sand and gravel, Earth Surf. Process. Land., 43, 3086-3098, https://doi.org/10.1002/esp.4471, 2018.

Vanacker, V., Vanderschaeghe, M., Govers, G., Willems, E., Poesen, J., Deckers, J., and De Bievre, B.: Linking hydrological, infinite slope stability and land-use change models through GIS for assessing the impact of deforestation on slope stability in high Andean watersheds, Geomorphology, 52, 299-315, https://doi.org/10.1016/S0169-555X(02)00263-5, 2003.

Vanacker, V., von Blanckenburg, F., Hewawasam, T., and Kubik, P. W.: Constraining landscape development of the Sri Lankan escarpment with cosmogenic nuclides in river sediment, Earth Planet. Sc. Lett., 253, 402-414, https://doi.org/10.1016/j.epsl.2006.11.003, 2007.
Van den Berg, F., Schlunegger, F., Akçar, N., and Kubik, P.: ${ }^{10}$ Be-derived assessment of accelerated erosion in a glacially conditioned inner gorge, Entlebuch, Central Alps of Switzerland, Earth Surf. Process. Land., 37, 1176-1188, https://doi.org/10.1002/esp.3237, 2012.

Walling, D. E.: The sediment delivery problem, J. Hydrol., 65, 209237, https://doi.org/10.1016/0022-1694(83)90217-2, 1983.

Wang, W., Godard, V., Liu-Zeng, J., Scherler, D., Xu, C., Zhang, J., Xie, K., Bellier, O., Ansberque, C., de Sigoyer, J., and Team, A.: Perturbation of fluvial sediment fluxes following the 2008 Wenchuan earthquake, Earth Surf. Process. Land., 42, 26112622, https://doi.org/10.1002/esp.4210, 2017.

West, A. J., Hetzel, R., Li, G., Jin, Z., Zhang, F., Hilton, R. G., and Densmore, A. L.: Dilution of ${ }^{10} \mathrm{Be}$ in detrital quartz by earthquake-induced landslides: Implications for determining denudation rates and potential to provide insights into landslide sediment dynamics, Earth Planet. Sc. Lett., 396, 143-153, https://doi.org/10.1016/j.epsl.2014.03.058, 2014

Wheaton, J. M., Brasington, J., Darby, S. E., and Sear, D. A.: Accounting for uncertainty in DEMs from repeat topographic surveys: improved sediment budgets, Earth Surf. Process. Land., 35, 136-156, https://doi.org/10.1002/esp.1886, 2010.

Whipple, K. X. and Tucker, G. E.: Dynamics of the streampower river incision model: Implications for height limits of mountain ranges, landscape response timescales, and research needs, J. Geophys. Res., 104, 17661-17674, https://doi.org/10.1029/1999JB900120, 1999.

Wittmann, H., von Blanckenburg, F., Kruesmann, T., Norton, K. P., and Kubik, P. W.: Relation between rock uplift and denudation from cosmogenic nuclides in river sediment in the Central Alps of Switzerland, J. Geophys. Res.-Earth, 112, 1-20, https://doi.org/10.1029/2006JF000729, 2007.

Yanites, B. J., Tucker, G. E., and Anderson, R. S.: Numerical and analytical models of cosmogenic radionuclide dynamics in landslide-dominated drainage basins, J. Geophys. Res.-Earth, 114, F01007, https://doi.org/10.1029/2008JF001088, 2009. 